\title{
OBSERVATIONS ON THE MATURATION STAGES OF THE PARTHENOGENETIC AND SEXUAL EGGS OF HYDATINA SENTA
}

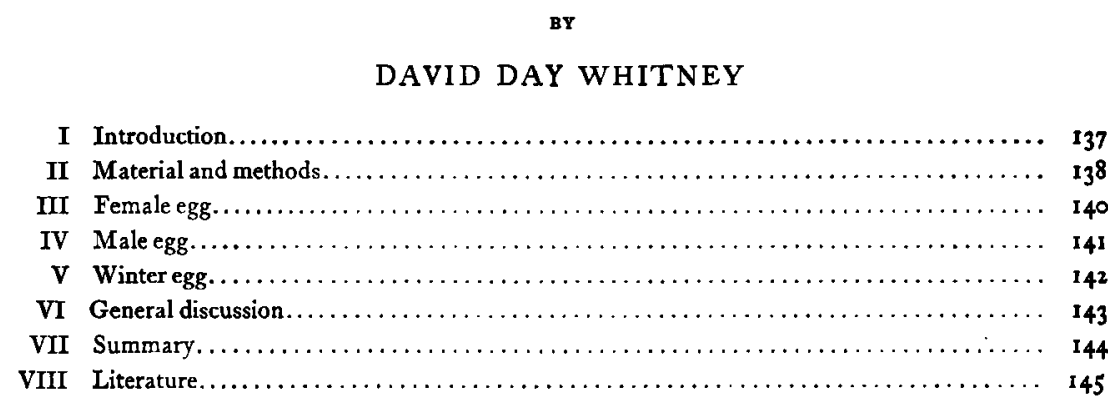

\section{INTRODUCTION}

Despite the experiments that have been carried out by several workers to discover how sex is determined in parthenogenetic eggs the attempts to show that such external factors as temperature or food influence the result do not appear to have been successful. Attention has turned more recently to the possibility that there are internal factors in the eggs that are all-important in producing males or females.

As early as I 845 Dzierzon brought forward very strong evidence to show that the eggs of the honey-bee, Apis mellifica, always develop into males if unfertilized, but if fertilized they develop into females (queens or workers). In other words, internal rather than external agents bring about the result. This theory has been often attacked and strongly defended, and now seems to be generally accepted.

In the aphids Balbiani and Stevens find that the same female may produce both male parthenogenetic and fertilized or winter eggs. Lauterborn finds the same phenomenon in the Rotifer, Asplanchna, and Issakowitsch in a Daphnid. Whether the eggs that are fertilized are originally male eggs or develop from a dif-

The Journal of Experimental Zoölogr, vol. vi, no. I. 
ferent part of the ovary is not certain, but the evidence seems to indicate that they are male eggs.

In the two kinds of parthenogenetic eggs of some of the aphids Stevens finds that there is no reduction in the number of the chromosomes during the formation of the polar body. Lenssen, in a study of the parthenogenetic eggs of the Rotifer, Hydatina senta, finds that there is a reduction in the number of the chromosomes during the formation of the polar body in the male egg but no reduction in the female egg.

Weismann found that both kinds of parthenogenetic eggs of Polyphemus (Daphnid), certain Ostracods and Rotifers produced only one polar body while the fertilized eggs produced two polar bodies. Blochmann and Stevens found the same relation to hold for certain aphids.

In Lisparis dispar, a parthenogenetic Lepidopteran, Platner found that two polar nuclei were formed. In the bee apis, Blochmann, Paulcke, Petrunckewitsch and others find that the parthenogenetic eggs which develop into male animals give off two polar bodies. In the Rotifer, Asplanchna, Mrazek, Erlanger and Lauterborn found that the female parthenogenetic egg gave off one polar body and that the male parthenogenetic as well as the fertilized egg gave off two polar bodies. In the parthenogenetic eggs of Hydatina senta Lenssen thought that the male egg gave off one polar body and the female egg gave off none!

At the suggestion and under the supervision of Prof. T. $H$. Morgan the following work upon the eggs of Hydatina senta was done with the view of obtaining more light upon the maturation stages and their relation to the determination of sex.

I am also indebted to Prof. E. B. Wilson for many valuable suggestions and criticisms.

\section{MATERIAL AND METHODS}

The Rotifers were collected and reared in cultures as described in a former paper.

The first maturation spindle is formed before the egg is laid and in order to study the early maturation stages animals con- 
taining eggs were killed and fixed in masses of thousands and sectioned in toto. Many eggs were found in the desired stages, but as the eggs are filled with yolk granules of various sizes it was exceedingly difficult to find many sections in which the yolk granules were not. mingled with the chromosomes.

Hot sublimate acetic, Bouin's fluid, strong Flemming, Gilson, Carnoy, and alcohol acetic, were used as killing and fixing fluids. Some good preparations were obtained by each method, but alcohol acetic gave the best results in obtaining equatorial plates; for it coagulated the cytoplasm of the egg in such a way as to embed the yolk granules in its meshes, thus leaving the spindle and its chromosomes free from yolk granules. Thousands of animals were sectioned and about three hundred good slides were made. Sections were cut $5 \mu$ in thickness in $5^{\circ}$ to $52^{\circ} \mathrm{C}$. paraffine.

Many parthenogenetic females were also isolated separately and the sex of their offspring determined, for those eggs first laid, before the females were killed and sectioned. The general nature of the maturation stages of such eggs was determined before a more detailed study was made of the eggs in the mixed slides.

After the eggs are laid the envelope around them is so thin and at the same time so exceedingly impervious to fixing fluids that the eggs usually collapse in the process of fixation. Sometimes a few do not collapse in alcohol acetic but, however careful one may be, by the time the eggs are embedded they have shrunken. In such eggs the yolk granules are so crowded in among the chromosomes and stain so darkly that no satisfactory results can be obtained.

In order to free the spindle from these granules the eggs were first centrifuged. In sections of such eggs the maturation spindle remained in the clear middle zone of the egg and was often entirely free from yolk granules. As only a few sections of these eggs were made no good stages were found in which the chromosomes could be counted but the method gives promise of results that can not be obtained in other ways.

Heidenhain's iron hæmatoxylin was used chiefly and gave the best results although many other stains were tried.

In order to see the polar bodies the eggs, some time after they 
were laid, were put into Schneider's aceto-carmine for about thirty seconds and then into a water-glycerine solution ( $\mathrm{I}$ drop in $5 \mathrm{cc}$. of water). The blastomeres become separated and the polar bodies can be readily seen.

\section{FEMALE EGG}

The female egg is easily distinguished from the male egg by its larger size and is never mistaken for the winter egg which may be of equal size, but has a much thicker envelope around it, besides containing the conspicuous sperm nucleus.

In the female parthenogenetic egg the number of chromosomes was never definitely determined but many spindles in metaphase were seen in side view, containing numerous chromosomes (20 to

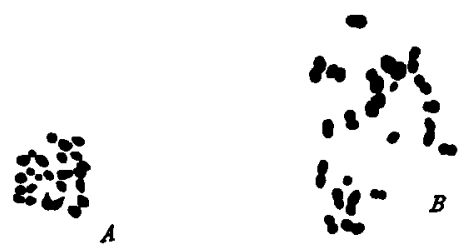

Fig. I Female parthenogenetic egg. $A$, equatorial plate of the polar spindle, showing twentythree to twenty-five chromosomes; $B$, prophase of polar spindle, showing twenty-two chromosomes.

30). In one polar view of a metaphase twenty-five chromosomes were seen, Fig. I, $A$. In a prophase twenty-two dumb-bel shaped chromosomes were seen in one section (Fig. I, $B$ ) and in the adjoining section there were four other dumb-bell shaped chromosomes together with one that was not constricted. No anaphase or telophase stages were found although hundreds of eggs were examined. Lenssen found the chromosomes somewhat scattered about on the equator of the maturation spindle and concluded they were in an early anaphase but since he considered the unreduced number to be ten or twelve chromosomes the twenty or more chromosomes that he saw were probably in an early meta-

Notz-The drawings of the chromosomes were made as carefully as possible with a camera under a $1.5 \mathrm{~mm}$. Zeiss apochromatic and compensation ocular 6 . They were then enlarged with a drawing camera about three times, corrected by comparison with the objects, and reduced by one-third in reproduction. 
phase instead of in an early anaphase. He never saw a telophase stage and decided without any evidence that the chromosomes never separated beyond the early anaphase stage and that later all the chromosomes form the segmentation nucleus.

This is probably not the case because one polar body can always be seen near the periphery of the egg after the first cleavage, in total mounts prepared by the method already described. Sometimes a constriction can be seen across the middle of the polar body giving it the appearance of being divided into two parts. In the two-cell stage of the egg after the two blastomeres separate the polar body is always found in the space between the two cells (Fig. 2, $A-B$ ). In the four-cell stage it is seen at the point of juncture of the four cells (Fig. 2, $C$ ).
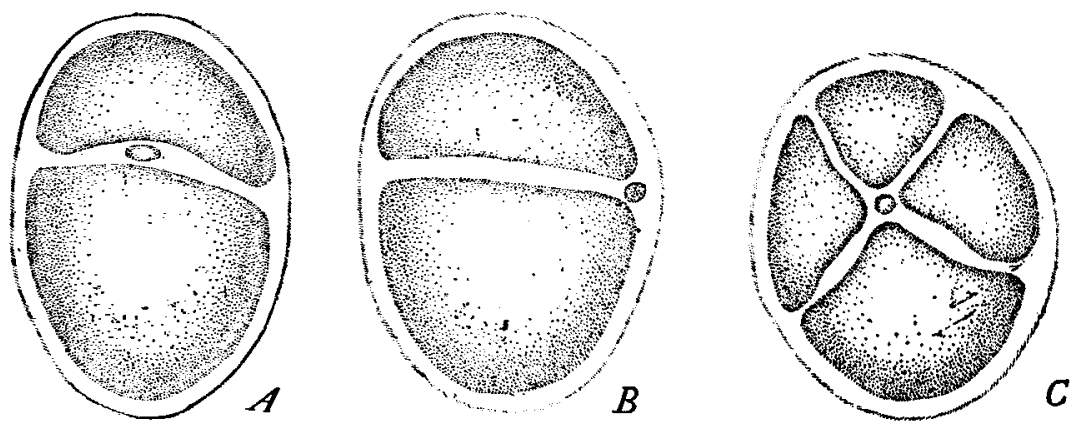

Fig. 2 Female parthenogenetic egg. $A, B$, eggs in the two-cell stage, showing one polar body; $C$, egg in the four-cell stage, showing one polar body at the intersection of the two cleavage planes.

IV MALE EGG

The male egg is much smaller than the other two kinds of eggs and has a thin envelope around it similar to that of the female parthenogenetic egg. The maturation spindle was seen several times when the chromosomes were in metaphase, anaphase and telophase stages. In two cases of telophase ten and fourteen chromosomes respectively were counted on one end of the spindle (Fig. 3, $C-D$ ). Polar views of the metaphase stage showed clearly eleven to thirteen chromosomes (Fig. 3, $A-B$ ). They were always less in number and larger in size than the chromosomes in the metaphase stage of the female parthenogenetic eggs. 
Three polar bodies are to be found near the periphery of the egg close to the line of meeting of the blastomeres. One was usually larger than the other two and often at a little distance away from them (Fig. 4, $A-B$ ), although in one instance the three polar bodies were close together and seemed to be of the same size (Fig. 4, C).
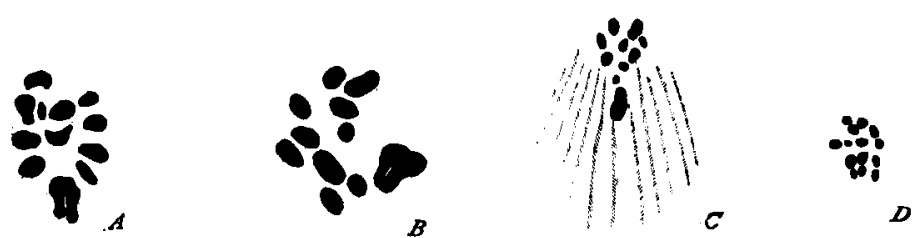

Fig. 3 Male parthenogenetic egg. $A, B$, equatorial plates of the polar spindle, showing twelve to thirteen chromosomes; $C, D$, polar spindle in telophase, showing ten to fourteen chromosomes.

Lauterborn states that in the male parthenogenetic egg of Asplanchna the first of the two polar bodies which was extended usually divided.

Lenssen concluded that only one polar body was formed because he saw the maturation spindle in the telophase stage. He did not follow the history of the chromosomes in the later stages and consequently never saw any polar bodies.
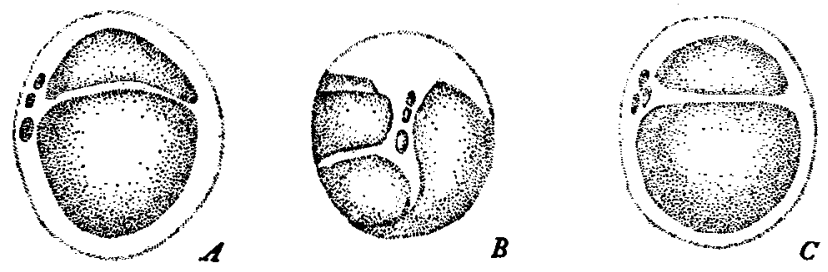

Fig. 4 Male parthenogenetic egg. $A, B$, eggs in the four-cell stage, showing three polar bodies, two of which are smaller than the other; $C$, egg in the two-cell stage, showing three polar bodies of nearly the same size.

\section{WINTER EGG}

The fertilized or winter egg has a very thick envelope. An oval shaped small body which is probably the sperm nucleus is always found near the egg nucleus.

The chromosomes were seen in sections on the maturation spindle (side view) in all stages but in only two anaphase stages (Fig. 5, 
$C-D)$, could they be counted because of being too closely crowded together. The polar view of the metaphase in the alcohol acetic fixation gave the best results. Fourteen chromosomes were seen in several sections of different eggs (Fig. 5, $A-B$ ). The chromosomes were of about the same size as those in the metaphase of the male parthenogenetic egg and were much larger in size and less in number than those in the metaphase of the female parthenogenetic egg.
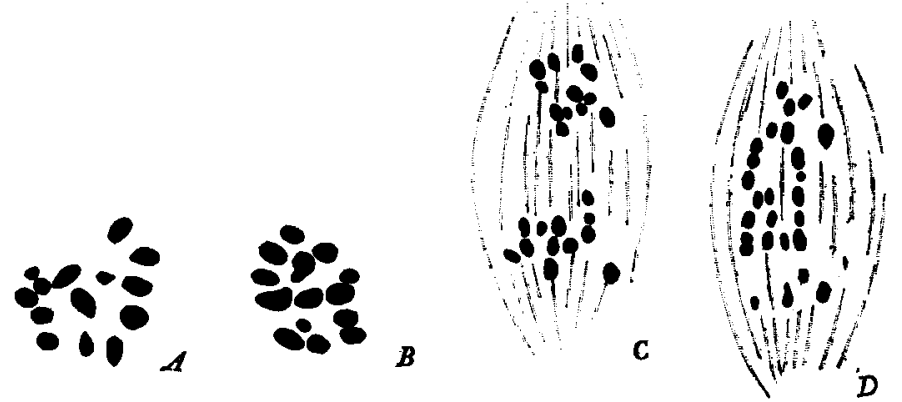

Fig. 5 Winter or fertilized egg. $A, B$, equatorial plates of the polar spindle, showing fourteen chromosomes; $C, D$, anaphases of the polar spisdle, showing twelve to fourteen chromosomes on each end of the spindle.

On account of the thick and opaque egg envelope, the polar bodies were never seen.

\section{GENERAL DISCUSSION}

Although Lenssen was mistaken in regard to the number of the chromosomes nevertheless he was firmly convinced that the number in the maturation stages of the male parthenogenetic and the fertilized egg were the same and that the number in the female parthenogenetic egg was greater. By comparing my Figs. I, 3 and 5 , it will be seen that this conclusion is confirmed. The greatest number of chromosomes seen in an equatorial plate of the male egg was possibly thirteen and the number seen in an equatorial plate of a winter egg was fourteen. The chromosomes of both eggs in the same stages were of the same size.

In the female parthenogenetic egg the greatest number of chromosomes seen was twenty-five (Fig. I). The chromosomes were 
very much smaller than in the other two kinds of eggs and usually were so crowded together that it was impossible to count them except in a very few cases.

These observations show that there is probably a reduction in the number of chromosomes in the male parthenogenetic and winter egg but no reduction in the female parthenogenetic egg. The former case would be similar to what occurs in the honeybee. In the aphids Stevens found that there is no reduction in the number of chromosomes in either of the male or female parthenogenetic eggs but only in the fertilized egg.

It appears that in different animals parthenogenetic eggs vary in the number of polar bodies that they give off. The male egg of Asplanchna, Hydatina and Apis gives off two polar bodies while the male egg of aphids gives off only one.

If it is true that the male egg when fertilized becomes the winter egg which develops into a female it seems evident that the reduction in the number of chromosomes and the formation of the second polar body is not in itself the factor that determines the ultimate sex of the egg.

The sperm would seem to introduce a factor that determines the sex of the embryo. This idea is strongly suggested by the evidence that Meves has brought forward in the case of the honeybee in which he finds that only one kind of functional sperm is produced. Morgan also finds a similar phenomenon for certain Phylloxerans. If the same process occurs in the sperm of Hydatina the cause of the change in sex of the male egg may be at least surmised.

\section{SUMMARY}

I In the female parthenogenetic egg of Hydatina senta there is no reduction in the number of chromosomes during maturation. One polar body is extruded.

2 In the male parthenogenetic egg there is a reduction in the number of chromosomes during maturation. Two polar bodies are formed, one of which subsequently divides.

3 In the winter egg, that becomes fertilized, there is a reduction in the number of chromosomes during maturation, and since 
a similar process of reduction takes place in the parthenogenetic egg that becomes a male it would seem to follow that the sex of the embryo from this egg is changed by the spermatozoön.

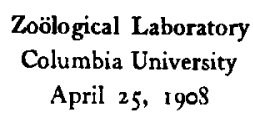

\section{LITERATURE CITED}

Balbiani, E. G. '69-'72-Mémoire sur la génération des aphides. Am. Sc. Nat. Ser. 5, Zool., T. LI, I869; T. 14, 1870; T. 15, 1872.

Blochmann, F. '88-Ueber die Richtungskörper bei unbefruchtet sich entwickelnden Insekteneiern. Verh. naturh. med. Ver. Heidelberg, N. F., vol. iv, no. 2.

'89-Ueber die Zahl. der Richtungskörper bei befruchteten und unbefruchteten Bieneneiern. Verh. naturh. med. Ver. Heidelberg, N. F., vol. iv, pp. 239-4I; fr. R. Mic. Loc., 1889.

Brauer, A. '94-Zur Kenntniss der Reifung des parthenogenetisch sich entwickelnden Eies von Artemia salina. Arch. mikr. Anat., vol. xi.

Castle, W. E. 'o3-The Heredity of Sex. Bull. of the Mus. of Comp. Zoöl. Harvard College. vol. xl, no. 4.

Dzierzon, J. '45-' $76-[$ For a complete list of the writings of Dzierzon, see Bibliotheca Zoologica, ii, p. 2270.]

Erlanger u. LaUterborn '97-Ueber die ersten Entwickelungsvorgänge im parthenogenetischen und befruchteten Räderthierei. Zool. Anz., vol. $x x$.

Issakowitsch, A. '05-Geschlechtsbestimmende Ursachen bei den Daphniden. Biol. Centralb., xxv.

LaUterborn, R. '98-Ueber die cyclische Fortpflanzung limnetischer Rotatorien. Biol. Centralbl., xviii.

Lenssen '98-Contribution à l'étude du developpement et de la maturation des œufs chez Hydatina senta. La Cellule, xiv.

Maupas, M. ' $9 \mathrm{I}-$ Sor le déterminisme de la sexualité chez l'Hydatina senta, Ehr. C. R. Ac. Sc. Paris, cxiii.

Meves, F. '07-Die Spermatocytenteilungen bei der Honigbiene. Arch. mikr. Anat., lxx.

Morgan, T. H. 'o8-The Production of Two Kinds of Spermatozoa in Phylloxerans. Functional "Female Producing" and Rudimentary Spermatozoa. Proceedings of the Society for Experimental Biology and Medicine, vol. v, no. 3 . 
MrazeK, AL. '97-Zur Embryonalentwickelung der Gattung Asplanchna. Jahresb. böhna Ges., 2, pp. I-II.

Nussbaum, M. '97-Die Entstehung des Geschlechts bei Hydatina senta. Arch. mikr. Anat., xlix.

Paulcke, W. '99-Zur Frage der Parthenogenetischen der Drohnen. Anat. Arzz, vol. xvi.

Petrunkewitsch, A. 'oi-Die Richtungskörper und ihr Schicksal im befruchteten und unbefruchteten Bienenei. Zool. Jahrb., vol. xiv.

Phillips, E. F. '03-A Review of Parthenogenesis. Amer. Phil. Soc., vol. xlii. Platner, G. '88-Die erste Entwickelung befruchteter und parthenogenetischer Eier von Lisparis dispar. Biol. Centrabl., vol. viii, no. 17.

'89-Ueber die Bedeutung der Richtungskörperchen. Biol. Centrabl. vol. viii.

Stevens, N. M. '04-A study of the Germ Cells of Aphis rosæ and Aphis œenotheræ Journ. Exp. Zoöl,, vol. ii.

Weismann and Ischikawa '88-Weitere Untersuchungen zum Zahlengesetz der Richtungskörper. Zool. Jahrb., vol. iii.

Weismann, A. '80-Parthenogenesis bei den Ostracoden. Zool. Anz., iii.

Whitney, D. D. 'o7-Determination of Sex in Hydatina senta. Journ. Exper. Zoöl., vol. v.

Wilson, E. B., '05-Studies on Chromosomes. Jour. Exp. Zoöl,, vols. ii and iii. 